\title{
High Performance Liquid Chromatographic Procedure for the Simultaneous Determination of Theophylline, Caffeine, and Phenobarbital in Neonates
}

\author{
By R. Soto-Otero, E. Mendez-Alvarez and G. Sierra-Marcuño \\ Department of Biochemistry, School of Medicine, University of Santiago de Compostela
}

(Received November 14, 1984/January 24, 1985)

Summary: A sensitive HPLC method is reported for the simultaneous determination of theophylline, caffeine, and phenobarbital in $100 \mu$ of plasma.

After a single extraction of the drugs with chloroform/isopropanol ( $90 \div 10$ by volume) at low $\mathrm{pH}$ in the presence of an excess of ammonium sulphate they are resolved and quantified using a reversed-phase column (Spherisorb 5 ODS). The drugs are eluted with a binary-solvent gradient system (acetonitrile/phosphate buffer $\mathrm{pH}$ 4.6) at room temperature and monitored at $204 \mathrm{~nm}$. Quantitation is based on peak-height ratio of analyte to interval standard (8-chlorotheophylline).

Complete chromatographic resolution of all drugs is achieved within $15 \mathrm{~min}$. The method is linear to $40 \mathrm{mg} / \mathrm{l}$ of theophylline and caffeine, and to $80 \mathrm{mg} / \mathrm{l}$ of phenobarbital. Numerous drugs and xanthine metabolites tested do not interfere.

Hochleistungsflüssigkeitschromatographisches Verfahren für die gleichzeitige Bestimmung von Theophyllin, Coffein und Phenobarbital bei Neugeborenen

Zusammenfassung: Eine empfindliche hochleistungsflüssigkeitschromatographische Methode für die gleichzeitige Bestimmung von Theophyllin, Coffein und Phenobarbital in $100 \mu$ l Plasma wird beschrieben.

Nach Extraktion der Aržneimittel mit Chloroform/Isopropanol $(90+10$, Volumina) bei niedrigem $\mathrm{pH}$ in Gegenwart eines Überschusses vơn Ammoniumsulfat erfolgen Trennung und Quantifizierung mit einer „reversed-phase“-Säule an Spherisorb 5 ODS. Die Arzneimittel werden bei Raumtemperatur mit einem binären Lösungsmittelgradienten (Acetonitril/Phosphatpuffer $\mathrm{pH} \mathrm{4,6)} \mathrm{eluiert} \mathrm{und} \mathrm{bei} 204 \mathrm{~nm}$ gemessen. Die Auswertung erfolgt aufgrund des Peakhöhen-Verhältnisses von Analyt und 8-Chlortheophyllin als internem Standard.

Die vollständige chromatographische Trennung der drei Arzneimittel wird innerhalb 15 Minuten erreicht. Die Methode ist linear bis $40 \mathrm{mg} / \mathrm{l}$ Thèophyllin und Coffein und bis $80 \mathrm{mg} / 1$ Phenobarbital. Zahlreiche Arzneimittel und Xanthinmetabolite wurden geprüft und stören das Verfahren nicht.

\section{Introduction}

Theophylline (1,3-dimethylxanthine) and caffeine (1,3,7-trimethylxanthine) are two drugs widely used in the prevention and treatment of neonatal apnoea (1). In neonates, theophylline is metabolized to caffeine, reaching medically significant levels in plasma $(2,3)$. For this reason, it is important to determine both drugs simultaneously in order to establish an optimal individual dose and to prevent toxicity. 
Recently, several HPLC methods have been developed for the analysis of theophylline, caffeine, and other methylated xanthines (4-6). However, no method has as yet been reported which permits the simultaneous determination of phenobarbital together with these drugs in a reasonable time period. Phenobarbital is, however, widely used as an enzyme inducer to prevent hyperbilirubinaemia in preterm neonates $(7,8)$. In addition, it is used in the treatment of convulsions, and it is sometimes used in combination with theophylline in the treatment of apnoea. The half-life of this drug in neonates is relatively long with a wide interindividual variability $(9-11)$. Thus, the simultaneous determination of phenobarbital would be very useful in order to avoid toxicity symptoms of this drug in neonates.

We report here a gradient reversed-phase liquid chromatographic method for a rapid, simultaneous determination of theophylline, caffeine, and phenobarbital in plasma. Plasma $(100 \mu \mathrm{l})$ was extracted, using an efficient single-step method, which can also be adapted to $50 \mu \mathrm{l}$ if necessary.

\section{Materials and Methods}

We used a Kontron HPLC system Model 620 (Zurich, Switzerland) coupled to a Uvikon variable wavelength ultraviolet spectrophotometer Model 720LC (Kontron AG), a Kontron programmer Model 200, and a Hewlett-Packard integrator Model 3390A (Avondale, PA 19311, U.S.A.). The column used was a Spherisorb ODS column, 5 micron particle size, $250 \mathrm{~mm} \times 4.6$ $\mathrm{mm}$ i.d. (Kontron AG). Samples were injected using a Rheodyne injector Model 7125 with a $20 \mu$ loop.

\section{Reagents and standards}

Acetonitrile was of HPLC grade (Fisher Scientific Co., Fair Lawn, NJ 07410, U.S.A.). Methanol, chloroform, and isopropanol were LiChrosolv ${ }^{\circledR i}$ (Merck, Darmstadt, F.R.G.). All the inorganic chemicals were of A. R. grade (Merck). HPLC grade water was prepared with the Norganic water purification system (Millipore Corp., Bedford, MA 01730, U.S.A.).

Theophylline, caffeine, and 8-chlorotheophylline were purchased from Sigma Chemical Corp..(St. Louis, MO 63178, U.S.A.). Phenobarbital was a gift from Bayer Laboratories (Barcelona, Spain).

Stock standards: these were prepared in methanol to give a concentration of $500 \mathrm{mg} / \mathrm{l}$ for theophylline, caffeine and 8chlorotheophylline, and $1 \mathrm{~g} / \mathrm{l}$ for phenobarbital.

Plasma standards: these were prepared in drug-free plasma in the range $0.5-40 \mathrm{mg} / \mathrm{l}$ (theophylline, caffeine) and $5-80 \mathrm{mg} / \mathrm{l}$ (phenobarbital).

Internal standard solution: this was prepared daily in water to give a concentration of $10 \mathrm{mg} / \mathrm{l}$.

Phosphate buffer: add $150 \mu \mathrm{l}$ of $1 \mathrm{~mol} / 1 \mathrm{KH}_{2} \mathrm{PO}_{4}$ to $1000 \mathrm{ml}$ of water and adjust to $\mathrm{pH} 4.6$ with $0.9 \mathrm{~mol} / 1 \mathrm{H}_{3} \mathrm{PO}_{4}$.
Mobile phase: solvent A - phosphate buffer; solvent B acetonitrile. Before use, the organic solvent was filtered and degassed by passing it through a $0.5 \mu \mathrm{m}$ Millipore filter type FHUPO4700 (Millipore Corp.) under reduced pressure. The buffer was passed under reduced pressure through a $0.45 \mu \mathrm{m}$ Millipore filter type HATF047EP.

Extraction solvent: chloroform/isopropanol $(90+10$ by volume).

Procedure

Plasma $(100 \mu \mathrm{l})$, internal standard $(100 \mu \mathrm{l})$ and one drop of 3 $\mathrm{mol} / \mathrm{l} \mathrm{HCl}$ are added to a glass stoppered centrifuge tube, then mixed by vortexing for $5 \mathrm{~s}$. Extraction solvent $(2.5 \mathrm{ml})$ is then added. After mixing (vortex) for $30 \mathrm{~s}$, about $200 \mathrm{mg}$ of crystalline ammonium sulphate are added with the aid of a calibrated spatula, and the tube contents are again mixed vigorously (vortex) for $30 \mathrm{~s}$. After centrifugation at $5000 \mathrm{~min}^{-1}$ for about $3 \mathrm{~min}$, the upper aqueous layer is aspirated and discarded, and the organic phase is decanted into a conical glass tube. Two millilitres of this organic phase are transferred by pipette to a second conical glass tube then evaporated to dryness at $60^{\circ} \mathrm{C}$ in a water bath under a gentle stream of air.

The dry residue is dissolved in methanol $(50 \mu \mathrm{l})$ and $20 \mu \mathrm{l}$ of this solution are injected into the chromatograph, maintaining a flow rate of $3 \mathrm{ml} / \mathrm{min}$. The effluent is monitored at $204 \mathrm{~nm}$.

The mobile phase composition is programmed as follows: The initial composition of solvents A/B is $97+3$ by volume. From time 0 to $15 \mathrm{~min}$, a linear gradient proceeds to a composition of solvents $\mathrm{A} / \mathrm{B}, 67+33$ by volume. From 15 to $15.5 \mathrm{~min}$, a linear gradient returns to the initial composition, allowing immediate injection of another sample. Chromatography is performed at room temperature.

Quantification is based on the peak-height ratio of the analyte to the internal standard.

\section{Results}

\section{Chromatograms}

Figure 1 shows typical chromatograms obtained with the reported procedure from extracts of a plasma blank and a plasma spiked with therapeutic levels of the assayed drugs.

\section{Linearity}

We have investigated the linearity of the peak-height ratios versus plasma drug concentrations in the following ranges: $0.5-40 \mathrm{mg} / \mathrm{l}$ for theophylline and caffeine, and 5-80 mg/l for phenobarbital. Results obtained using a linear regression analysis were:

theophylline:

slope $=0.131 \quad \mathrm{y}$-intercept $=0.022 \quad \mathrm{r}=0.999$

caffeine:

slope $=0.126 \quad \mathrm{y}$-intercept $=0.010 \quad \mathrm{r}=0.999$

phenobarbital:

slope $=0.400 \quad \mathrm{y}$-intercept $=.0 .000 \quad \mathrm{r}=0.999$ 


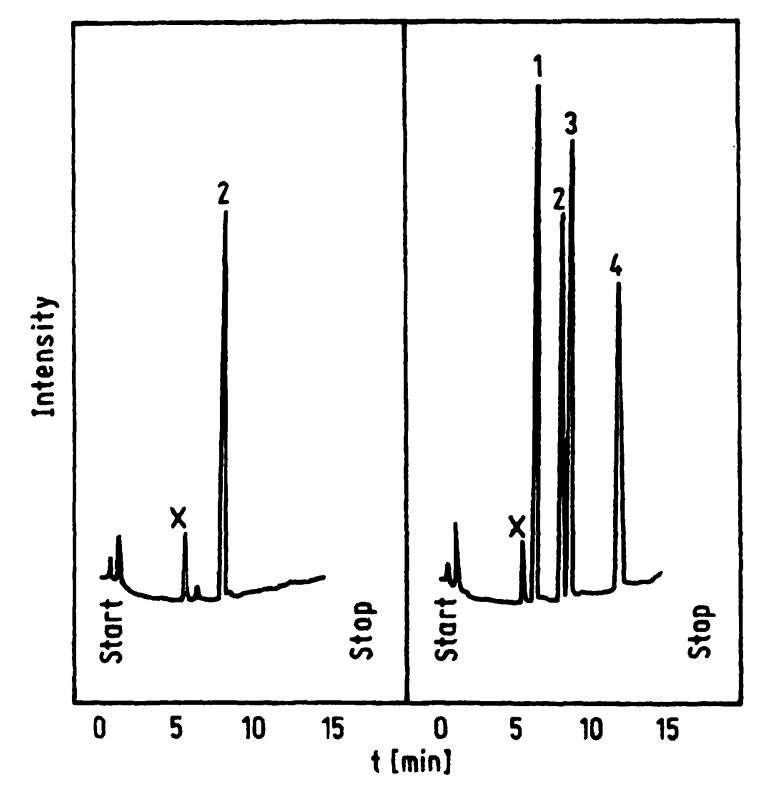

Fig. 1. Chromatogram of (left) a blank plasma and (right) a spiked plasma containing per litre: $10 \mathrm{mg}$ of theophylline (1), $10 \mathrm{mg}$ of caffeine (3), and $20 \mathrm{mg}$ of phenobarbital (4). Peak (2) is the internal standard and peak $(\mathrm{X})$ is an endogenous plasma component. Attenuation: $2^{7}$.

\section{Precision}

The precision of the method was determined by assaying plasma samples containing known quantities of the drugs. As shown in table 1 , within-day precision ranged from 1.2 to 6.2 , and between-day precision ranged from 1.6 to $6.7 \%$.

Tab. 1. Precision for the simultaneous determination of drugs in plasma.

\begin{tabular}{lccccc}
\hline Drug & Added & \multicolumn{2}{c}{$\begin{array}{l}\text { Within-day } \\
(\mathrm{n}=5)\end{array}$} & \multicolumn{2}{c}{$\begin{array}{l}\text { Between-day } \\
(\mathrm{n}=5)\end{array}$} \\
& & \multicolumn{2}{c}{$\begin{array}{c}\text { Mean CV } \\
\text { Mean CV }\end{array}$} & \multicolumn{2}{l}{ Mean } \\
& $(\mathrm{mg} / \mathrm{l})$ & $(\mathrm{mg} / \mathrm{l})(\%)$ & \multicolumn{2}{c}{$(\mathrm{mg} / \mathrm{l})$} & $(\%)$ \\
\hline Theophylline & 0.5 & 0.5 & 5.4 & 0.5 & 6.1 \\
& 5 & 5.1 & 4.0 & 5.0 & 5.7 \\
& 10 & 10.4 & 3.7 & 10.3 & 4.9 \\
& 20 & 20.2 & 2.4 & 20.7 & 2.5 \\
Caffeine & 40 & 41.4 & 1.9 & 41.2 & 1.8 \\
& 0.5 & 0.5 & 6.2 & 0.4 & 6.7 \\
& 5 & 4.9 & 5.1 & 4.7 & 5.0 \\
& 10 & 10.0 & 4.3 & 10.1 & 3.8 \\
Phenobarbital & 20 & 19.7 & 2.7 & 19.4 & 3.1 \\
& 40 & 40.1 & 1.9 & 40.5 & 1.7 \\
& 5 & 5.0 & 4.3 & 5.4 & 4.6 \\
& 10 & 10.6 & 3.7 & 10.5 & 4.0 \\
& 20 & 20.3 & 2.1 & 21.0 & 3.1 \\
& 40 & 41.1 & 1.7 & 40.6 & 2.8 \\
& 80 & 80.9 & 1.2 & 79.2 & 1.6 \\
\hline
\end{tabular}

\section{Recovery}

We determined the analytical recovery of the assayed drugs from plasma by comparing the peak-height ratios of extracted samples and external standard, with those of equivalent amounts of drugs and internal standard dissolved in methanol and chromaiographed directly. As shown in table 2, recoveries ranged from $92 \%$ to $102 \%$.

Tab. 2. Analytical recovery of drugs from plasma.

\begin{tabular}{lccl}
\hline Drug & $\begin{array}{l}\text { Added } \\
(\mathrm{mg} / \mathrm{l})\end{array}$ & $\begin{array}{l}\text { Recovered } \\
(\mathrm{mg} / \mathrm{l})\end{array}$ & $\begin{array}{l}\text { Recovery } \\
(\%)\end{array}$ \\
\hline Theophylline & 0.5 & 0.51 & 102 \\
& 5 & 5.0 & 100 \\
& 10 & 9.9 & 99 \\
& 20 & 19.8 & 99 \\
Caffeine & 40 & 39.6 & 99 \\
& 0.5 & 0.46 & 92 \\
& 5 & 4.7 & 94 \\
& 10 & 9.4 & 94 \\
Phenobarbital & 20 & 19.0 & 95 \\
& 40 & 38.8 & 97 \\
& 5 & 4.9 & 98 \\
& 10 & 9.8 & 98 \\
& 20 & 19.8 & 99 \\
& 40 & 39.6 & 99 \\
& 80 & 79.3 & 99 \\
\hline
\end{tabular}

\section{Interferences}

Table 3 shows the retention time of the drugs tested for potential interference relative to the internal standard. Of these drugs, only paraxanthine (1,7dimethylxanthine), a metabolite of caffeine, co-elutes with theophylline. However, paraxanthine, which may exist in patients consuming coffee, is not present in the plasma of neonates $(2,12)$. Drugs tested but not eluted within $15 \mathrm{~min}$ were: phenytoin, clonazepam, carbamazepine, diazepam, and methaqualone.

Tab. 3. Relative retention times (internal standard $=1.00$ ).

\begin{tabular}{ll}
\hline Drug & Relative retention time \\
\hline 3-Methyluric acid & 0.46 \\
3-Methylxanthine & 0.53 \\
Salicylate & 0.56 \\
1,3-Dimethyluric acid & 0.57 \\
Procainamide & 0.58 \\
Acetaminophen & 0.60 \\
Theobromine & 0.71 \\
Dyphylline & 0.76 \\
Theophylline & 0.79 \\
1,7-Dimethylxanthine & 0.79 \\
Ethosuximide & 0.83 \\
Acetylsalicylic acid & 0.91 \\
N-Acetylprocainamide & 0.95 \\
8-Chlorotheophylline & 1.00 \\
Caffeine & 1.06 \\
Phenobarbital & 1.47 \\
Phenytoin & 2.14 \\
Clonazepam & 2.19 \\
Carbamazepine & 2.24 \\
Diazepam & 2.35 \\
Methaqualone & 2.40 \\
\hline
\end{tabular}




\section{Discussion}

We performed the extraction with a mixture of organic solvents in the presence of excess of ammonium sulphate. This procedure causes virtually complete precipitation of plasma proteins (13), which otherwise would contaminate the column and the injection system (14). The use of a low $\mathrm{pH}$ improves the analytical recovery of some drugs and allows the precipitation of some plasma lipid components. In the extraction we recommend vigorous vortex-mixing for a few seconds rather than continous vortexing, in order to avoid the formation of an emulsion. We used methanol to redissolve the dried extract because it does not affect the shape of peaks and, furthermore, increases the analytical recovery of theophylline.

We found it necessary to use a mobile-phase gradient because low concentrations of acetonitrile are essential for a good resolution of theophylline, caffeine,

\section{References}

1. Aranda, J. \& Turmen, T. (1979) Clin. Perinatol. 6, 87-108.

2. Bory, C., Baltassat, P., Porthault, M., Bethenod, M., Frederich, A. \& Aranda, J. (1979) J. Pediat. 94, 988-993.

3. Standefer, J. \& Callaway, S. (1981) Clin. Chem. 27, 1086.

4. Muir, K., Kunitani, M. \& Riegelman, S. (1982) J. Chromatogr. 231, 73-82.

5. Ou, C. \& Frawley, V. (1983) Clin. Chem. 29, 1934-1936.

6. Klassen, R. \& Stavric, B. (1983) J. Liq. Chromatogr. 6, 895-906.

7. Salle, B., Pasquer, P., Desebbe, C., Rouzioux, J. \& Barouty, B. (1977) Helv. Paediatr. Acta 32, $221-226$.

8. Wallin, A. \& Boréus, L. (1984) Acta Paediat. Scand. 73, $488-497$.

9. Boréus, L., Jalling, B. \& Kallberg, N. (1978) Acta Paediat. Scand. 67, 193-200. and some of their metabolites, while high concentrations of acetonitrile are necessary for a rapid elution of phenobarbital. 8-Chlorotheophylline was chosen as internal standard for its position in the chromatogram and for its good analytical recovery. Phosphate buffer pH 4.6 was found to play an important role in obtaining a góod resolution between caffeine and the internal standard. The column effluent was monitored at $204 \mathrm{~nm}$ because this wavelength provides adequate sensivity for all the assayed drugs.

To prevent build-up of any strongly retained materials on the HPLC column, the chromatographic system was purged at the end of each workday with water for $15 \mathrm{~min}$ followed by acetonitrile for other $15 \mathrm{~min}$, at a flow rate of $3 \mathrm{ml} / \mathrm{min}$.

The method as reported here uses $100 \mu$ of plasma, but its high sensitivity permits adaptation to $50 \mu \mathrm{l}$ if desirable.

10. Pitlick, W., Painter, M. \& Pippenger, C. (1978) Clin. Pharmacol. Ther. 3, 346-350.

11. Aymard, P., Taburet, A., Baudon, J., Blanc, A., Hervé, J. \& Costil, J. (1980) In: Antiepileptic Therapy: Advances in Drug Monitoring (Johannessen, S. I., Morselli, H., Pippenger, C. E., Richens, A., Schmidt, D. \& Meinardi, H., eds.) Raven Press, New York, pp. 1-5.

12. Baird-Lambert, J., Doyle, P., Thomas, D., Jager-Roman, E., Cvejic, M. \& Buchanan, N. (1984) Dev. Pharmacol. Ther. 7, 239-244.

13. Blanchard, J. (1981) J. Chromatogr. 226, 455-460.

14. Bowie, L., Brucker, R., Floyd, R. \& Gochman, N. (1979) Clin. Chem. 25, 1129.

Prof. R. Soto-Otero Dept. of Biochemistry

School of Medicine

San Francisco, s/n

Santiago de Compostela

Spain 